\title{
PERSPECTIVAS E DESAFIOS PARA EDUCAÇÃO ESPECIAL E INCLUSIVA
}

\author{
Miguel Rodrigues Netto ${ }^{1}$
}

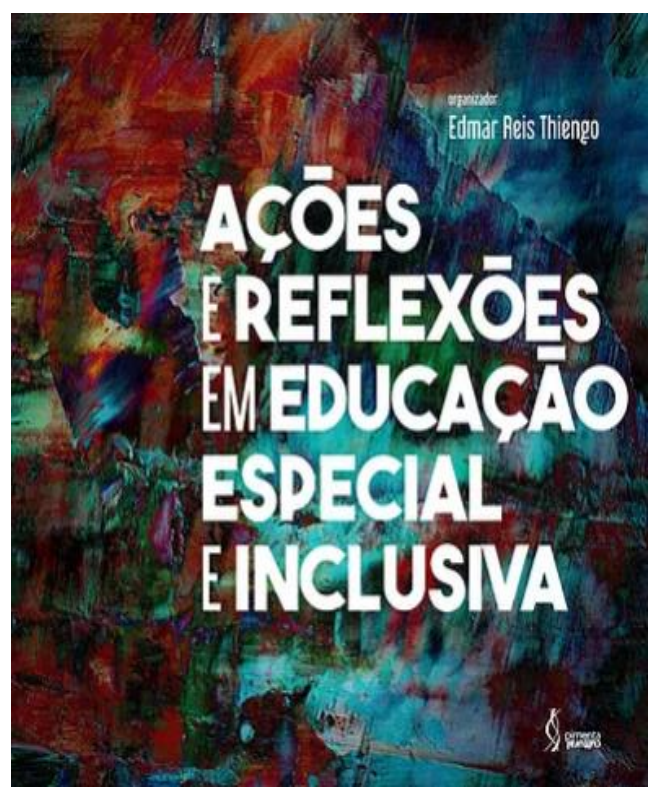

THIENGO, Edemar Reis (Org.). Ações e reflexões em educação especial e inclusiva. São Paulo: Pimenta Cultural, 2021.

A obra Ações e reflexões em educação especial e inclusiva apresenta o formato coletânea onde professores de diversas partes do país apresentam resultados de pesquisas sobre a educação especial, na perspectiva da educação inclusiva, colocando o humano como eixo central de suas discussões em sua capacidade de aprender e também lança importantes reflexões sobre o campo das políticas públicas de educação especial no Brasil. O livro é organizado por Edemar Reis Thiengo, Doutor em Educação pela Universidade Federal do Espírito Santo - UFES e professor do Instituto de Educação, Ciência e Tecnologia do Espírito Santo - IFES, onde atua no programa de Pós-Graduação em Educação em Ciências e Matemática - Educimat.

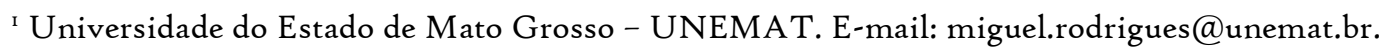


O prefácio do livro de autoria da professora Isabel Matos Nunes, da UFES, apresenta cada capítulo em perspectiva e alinhava com maestria a temática geral da obra com as especificidades trazidas pelos autores e autoras. A prefaciadora afirma que "Os textos que compõem esta coletânea são problematizadores e, portanto, se constituem em leitura essencial para os profissionais da educação. Cada texto anuncia pela via da pesquisa, do diálogo e do encontro com o outro, possibilidades de reflexão sobre o fazer educacional". A habilidade enunciativa da autora funciona bem como um chamariz que deixa aquele gostinho de quero mais na boca e chama para a leitura da obra em sua completude e complexidade.

O livro é composto por I4 capítulos que abordam temas caros a educação especial e inclusiva. Nos capítulos 2, 3 e 4 há uma concentração de esforços teóricos nos estudos sobre o transtorno do espectro autista. No capítulo 2, Carmo \& Thiengo abordam a Educação Inclusiva do adolescente autista: desafios para a família e a escola. No capítulo 3, Moreira \& Thiengo tematizam A criança autista na educação infantil: contribuições para sua socialização e fechando este bloco no capítulo 4, Silva \& Guisso debatem: O aluno autista no atendimento educacional especializado: um estudo de caso. As três pesquisas deste bloco apresentam aspectos conceituais, técnicos e especializados do tema, mas sua maior contribuição é o fluído debate acerca de possíveis caminhos a serem enfrentados por famílias, profissionais da educação e escolas junto aos alunos aos alunos. Sobre a conceituação é importante trazer a fala dos autores "O Transtorno do Espectro Autista (TEA) é considerado um transtorno de neurodesenvolvimento que apresenta características como a deficiência na interação e na comunicação social, comportamentos repetitivos e padrões estereotipados, apego aos objetos, que resultam em um isolamento extremo” (MOREIRA \& THIENGO, 2021, p. 59).

No capítulo 5, em Ensino de história a uma criança com Síndrome de Down: experiência com artes visuais, o leitor deve se cuidar para não terminar a leitura com os olhos marejados. A sutileza no trato com as palavras e a profundidade da abordagem trazem um engajamento quase espontâneo com a causa. Fontana \& Thiengo nos brindam com o relato de experiência envolvendo o professor e o aluno com Síndrome de Down num contexto totalmente inclusivo onde o ensino de história do Brasil é feito por meio de imagens. Segundo os autores os resultados da experiência são animadores quanto ao interesse e a interação com a criança, o que demonstra a importância de metodologias inovadoras na escola.

A Linguagem Brasileira de Sinais é a temática dos capítulos 6 e 7, onde Brito \& Thiengo, e Moço \& Abreu abordam, respectivamente: Construção relacional entre estudantes surdos e ouvintes: contribuições do intérprete de Libras; e Perspectiva de alunos sobre contribuições do intérprete da Libras nas aulas de educação física escolar. Nestas pesquisas de natureza qualitativa e descritiva trazem valiosos elementos sobre a atuação dos intérpretes de Libras, mostrando a importância deste profissional no cotidiano escolar. Aponta também para aspectos normativos do Plano Nacional de Educação Especial na Perspectiva Inclusiva - PNEEPI. Os 
autores apontam que o trabalho colaborativo requer dos envolvidos respeito aos conhecimentos e saberes especializados de cada profissional, confiança, horizontalização, igualdade, abertura à inovação e tempo de planejamento conjunto. Moço \& Abreu (202I).

Benevides \& Thiengo, bem como Mota \& Guisso debatem em seus respectivos capítulos 8 e 9: Desenvolvimento atencional de estudantes com TDAH: uso de tecnologias assistivas e Integração de alunos com TDAH no ensino fundamental: o uso da arterapia. Nestas pesquisas, evidencia-se os aportes pedagógicos das tecnologias assistivas e também o uso da Arteterapia que utiliza o processo criativo de fazer arte para melhorar o bem-estar físico, mental e emocional de pessoas com Transtorno do Déficit de Atenção e Hiperatividade -TDAH.

Nos demais capítulos do livro outros temas importantes como, aprendizagem de ciências em crianças com o Síndrome de Warkany; formação de professores para educação inclusiva; cantigas de roda na educação infantil e gestão democrática na educação especial nos convidam a uma leitura atenta pois em cada pesquisa vemos não apenas o fruto do esforço teórico empreendido, mas também o engajamento de cada pesquisador na consecução de tais políticas.

Podemos afirmar a partir do livro que o principal desafio para a efetivação de políticas públicas de educação especial na perspectiva da educação inclusiva está na saída desta modalidade da invisibilidade. Vemos ainda uma negação contínua do direito à educação consagrada na nossa Constituição Federal e também na Lei de Diretrizes e Bases da Educação. Os agentes que vivem o dia a dia da educação especial lutam com todas as forças por recursos e por um lugar de direito desta modalidade. Eles não querem favores, mas sim garantia de direitos.

O texto do PNEEPEI afirma que: “O movimento mundial pela educação inclusiva é uma ação política, cultural, social e pedagógica, desencadeada em defesa do direito de todos os alunos de estarem juntos, aprendendo e participando, sem nenhum tipo de discriminação”. Portanto, a mobilização social é mais do que necessária para a efetivação de medidas de atendimento da educação especial.

A obra cumpre bem o propósito de apresentar as ações nas mais diversas áreas da educação especial e também contribui para manter esta temática no centro das discussões acadêmicas, tendo em vista que são na sua maioria mestrandos que colocam à prova o fruto de seus trabalhos na certeza de que tais estudos não ficarão parados em estantes empoeiradas, mas sim ganharão vida nas escolas, nas universidades, enfim, nos lugares onde a educação e seus agentes militam. Com certeza uma excelente opção de leitura e fonte confiável para os que pesquisam nesta área. 